\title{
Developing undergraduate foundation courses in sustainability
}

\author{
Michael Howes ${ }^{1}$
}

\begin{abstract}
In 1992 the governments of the world committed themselves to pursue sustainable development at the Rio Earth Summit and education was promoted as playing a key role. The commitment was reaffirmed at subsequent summits culminating with the adoption of the United Nations Sustainable Development Goals in 2015 which included a specific goal on education. This paper examines how strategic changes can integrate the idea of sustainability into a range of programs at universities. A specific case study is used based on a first year course in environmental sustainability that the author convenes for a large and diverse group of undergraduate students from across all areas of the university. It is argued that in their future professional life, graduates have the potential to be agents of change by helping to transform the state, the private sector, and the community. This analysis is undertaken using the theoretical framework of ecological modernisation that underpins the idea of sustainability, offers a strategic pathway to transform public-privatecommunity interactions, and approaches sustainability as a design challenge. The somewhat ambitious goal is to synthesise the empirical evidence, the practical experience, and theoretical framework into a coherent whole.
\end{abstract}

Keywords: sustainability, education, interdisciplinary, ecological modernisation

\section{Introduction}

For a quarter of a century sustainability has been one of the stated goals of governments, businesses and community organisations around the world. Achieving sustainability, however, has proved elusive because the changes required cut across all areas of human endeavour (Howes, et al. 2017; Howes 2005). A wide range of professionals (e.g. scientists, planners, architects, engineers, policymakers, business managers, teachers, health workers, etc.) can play a key role by identifying problems, helping to find solutions, and/or working to overcome the barriers to change. How then can universities best prepare these graduates for the challenges they face? This paper addresses this question, starting with a brief history of sustainability followed by a discussion of the role allotted to education in various transition strategies. After that, an outline of the rise of environmental education at Griffith University is given. This leads to a discussion of a series of courses that were designed to give students in a broad range of disciplines an understanding of sustainability. A case study of a new first year course is then developed, which includes some of the practical lessons learnt with regards to what works and what pitfalls to avoid. The paper finishes by taking a step back and using the lens of ecological modernisation to understand the transformations required in pursuing sustainability, the role of graduates, and the elements that need to be included in their education. The underlying argument is that sustainability should be presented as a design challenge to students training for a wide range of professions and taught by way of interdisciplinary problem analysis/problem solving exercises.

The rise of sustainability to international prominence can be seen as a process of institutional learning by all sectors of society. At the end of the 1960s a rapidly expanding range of new social movements was forcing environmental and social issues onto the political agenda (Howes, 2005). This led to new initiatives that expanded the policy focus of governments beyond traditional areas such as security, economic management and welfare (Dryzek et al., 2003). During the 1970s the idea that economic,

\footnotetext{
${ }^{1}$ M. Howes

Griffith School of Environment, Cities Research Institute, Griffith University, Southport, QLD

4222, Australia

e-mail: m.howes@griffith.edu.au
} 
social and environmental issues were linked began to emerge. This process started with United Nations (UN) International Development Strategy in 1970 which linked economic development to a healthy environment. In 1972 concerns about the impacts of industrial development on the environment were the main focus of discussions at the UN Stockholm Conference on the Human Environment and this led to the subsequent creation of UN Environment Programme (UNEP).

A pivotal moment came in 1980 with the release of The World Conservation Strategy by UNEP, the International Union for the Conservation of Nature (IUCN) and the World Wildlife Fund (WWF). This introduced the concept of 'sustainable development' as a proposal to utilise ecosystem goods and services for the production of social and economic benefits over the long term (Howes 2005). The concept was elaborated by the World Commission on Environment and Development (WCED) in its final report, Our Common Future (WCED 1987) which offered what has become the most commonly used definition: "Sustainable development is development that meets the needs of the present without compromising the ability of future generations to meet their own needs" (WCED 1987, chapter 2, paragraph 1). Other sections of the report stated that there was a strategic role for education and institutional change in striving for sustainable development (WCED 1987, chapter 2, paragraph 16; chapter 4, section 3.2).

The idea was followed by the 1992 UN Conference on Environment and Development (UNCED), otherwise known as the Rio Earth Summit, that produced a strategy for reforms across many sectors of society called Agenda 21 (UNCED 1992). A commitment that appropriate education and professional training should be a priority appeared multiple times throughout this document (UNCED 1992). National initiatives were developed to supplement these international commitments, including: Australia's National Strategy for Ecologically Sustainable Development (1992); the President's Council on Sustainable Development (1993-1999) in the USA; and, Sustainable Development: the UK Strategy (1994) (Howes 2005). The Australian strategy, for example, had a chapter dedicated education and professional training (Ecologically Sustainable Development Steering Committee 1992, chapter 26). The principles of this strategy are still enshrined in current legislation, such as the Commonwealth Environment Protection and Biodiversity Act 1999.

So by the end of the twentieth century there were international agreements and national policies committing governments to pursue sustainable development. These included recognition that education was a key supporting mechanism that would enable professionals to fulfil a transformative role. These themes were revisited internationally at the 2002 Rio+10 and 2012 Rio+20 summits, as well as the 2015 UN Sustainable Development Goals, with Goal 4 focussed on education at all levels (UN 2015).

\section{Education and Sustainability}

It is important to note from the start that education relating to the environment goes back many generations before the rise of sustainability as an idea. One of the pioneers of environmental education was Patrick Geddes in late-Victorian Britain which preceded the growth of 'nature studies' in the early part of the twentieth century (Palmer 1998). The term 'environmental education' was introduced with the formation of the International Union for the Conservation of Nature and Natural Resources (IUCN) in the late-1940s and promoted at the UNESCO 1968 Biosphere Conference in Paris. There has, however, been some convergence between the two streams of environmental education and sustainability over the last few decades. The 1972 Stockholm conference mentioned previously, for example, generated a principle that stated:

"Education in environmental matters, for the younger generation as well as adults, giving due consideration to the underprivileged, is essential in order to broaden the basis for an 
enlightened opinion and responsible conduct by individuals, enterprises and communities in protecting and improving the environment in its full human dimension ..." (UN 1972, Principle 19).

UNEP, another product of the Stockholm conference, co-founded the International Environmental Education Programme (IEEP) and its 1977 conference in Tbilisi set out the principles of environmental education that remain current to this day:

- Life-long learning;

- An interdisciplinary curriculum;

- The interconnectedness of society and the environment;

- The multi-dimensional nature of environmental issues (including the social, political, economic and technological aspects);

- Energy and material resource limits;

- Global and future dimensions;

- Critical thinking and problem solving; and,

- Values and ethics (Palmer 1998).

These Tbilisi principles were picked up in Agenda 21 (UNCED 1992, chapter 36, paragraph 36.1).

The UN declared that 2005-14 would be the 'Decade of Education for Sustainable Development'. This entailed the acknowledgement of the need to include sustainability in the training of professionals that would help to transform society (Howlett, Ferreira and Blomfield 2016). There was a subsequent shift in emphasis from environmental education to education for sustainability amongst universities that had been developing such programs (Wilensky 2007). With the rise of climate change as one of the major threats to sustainability, there was a further shift in emphasis. The Australian Research Institute in Education for Sustainability (ARIES), for example, published a report in 2007 entitled Shifting Towards Sustainability: Education for Climate Change Adaptation in the Built Environment Sector. Disciplines such as planning, architecture and engineering were a particular focus of this report as their graduates can play a key role in climate change mitigation and adaptation for urban areas where the majority of the world's population now live (Lyth, Nichols and Tilbury 2007).

By the twenty first century education for sustainability was being incorporated into the curriculum for many tertiary students in Australia. The values and principles of sustainability were at the heart of these proposals in line with commitments within Agenda21, the National Strategy for Ecologically Sustainable Development, and the UN's Sustainable Development Goals. Such ideas have been injected into a somewhat turbulent academic environment in Australia of increased competition for scarce public resources, a shift to vocational training, and a growing tension between the demands of research and teaching (Davis 2006; Markwell 2007).

\section{Environmental Education at Griffith University}

Griffith University opened its doors to students in 1975 to meet the demands of the rapidly growing population and economy of South East Queensland. The teaching programs were deliberately designed to differentiate themselves from more traditional universities by being interdisciplinary and problemfocussed (Quirk 1996). The Australian School of Environmental Studies was one of the four founding schools and took this principle to its core by employing a wide range of both natural scientists (ecologists, chemists, geologists and mathematicians) and social scientists (economists, political scientists, geographers, sociologists and anthropologists). It was the first school of its type in Australia and remains the one of the largest in the country to this day (Metcalf 2000). A school of planning was created in 1993 that was then merged into a new and enlarged Griffith School of Environment in 2007. An architecture program was added during another expansion in 2009. 
Today the Griffith School of Environment has approximately 53 academic staff divided amongst six discipline groups: planning; architecture; marine science; society and environment; ecology and biodiversity; and, soil and water science. There are several research institutes associated with the school, including: the Cities Research Institute; the Environmental Futures Research Institute; and the Australian Rivers Institute. The author has worked at the school since 2000, was the founding Head of the Society and Environment Discipline, is currently the Deputy Head of School (Learning and Teaching), and has led several research projects within the Cities Research Institute and its forerunner the Urban Research Program.

In terms of teaching, the Griffith School of Environment offers undergraduate, Masters and $\mathrm{PhD}$ degrees in urban and environmental planning, architecture, environmental science and marine science. Since the start of 2014 all of the degrees offered by the school require students to take an interdisciplinary first year course that was designed and taught by the author of this paper entitled 1043SCG Introduction to Environmental Sustainability. This is the focus of the case study that follows and for convenience will be referred to as simply the 'sustainability course' from here onwards.

\section{Background to the Case Study: Forerunner Courses}

The current sustainability course has a long pedigree. Since its inception, the school of environment has worked through a series of different interdisciplinary first year courses that integrate the natural and social sciences. Three that were taught by the author have had a strong influence on the development of the current course: 1181ENV Sustainable Development; 1301ENV The Global Environment; and, 1161ENV Environmental Economics and Policy.

The first course, 1181ENV Sustainable Development, was created by the author in 2007 on the Nathan campus as a core for the environmental science and management students as well as an elective for the planning students. The original version of the course took a sector-based approach to sustainability. In the first few weeks the extent of interconnected environmental, social and economic problems was outlined. This was followed by an exploration of the idea of sustainable development as a solution and a set of principles were defined. The remaining two thirds of the course then methodically worked through how these principles could be applied to understanding and addressing issues relating to cities, housing, transport, energy, healthcare and manufacturing. The course was developed further after being taken over by colleagues in 2009 to promote more critical thinking and reflection (Howlett, Ferreira \& Blomfield 2016).

The second course, 1301ENV The Global Environment, had been running on the Gold Coast for more than a decade when the author took it over in 2009. The enrolments grew to 360 students with planning, architecture and environmental science comprising the main cohorts. It took an issue-based approach, looking at land degradation, climate change, the loss of biodiversity, pollution, hazardous waste, and water issues. The approach was based on Earth Systems science and used the driverspressures-state-impact-response (DPSIR) analytical framework. This framework is used for State of the Environment reporting by the United Nations, the European Union and the US EPA, as well as both federal and state environment departments in Australia. Although it was interdisciplinary, the natural sciences played a strong role in understanding the issues.

The third course, 1161ENV Environmental Economics and Policy, was jointly developed in 2009 by the author at the Gold Coast and his colleague, Dr Peter Daniels, at Nathan. Enrolments on the Gold Coast (where the author was teaching) consisted of 80 students, predominantly from planning. It took a discipline-based approach that was mainly social science but started with a review of key sustainability issues. It also touched on the DPSIR framework in conjunction with key economic and policy tools. Market theory was introduced, then environmental and social problems, such as 
pollution and climate change, were analysed as evidence of market failures. Economic tools such as contingent valuation and cost benefit analyses were then brought to bear on the issues discussed. This was backed up with a policy analysis of responses such as environmental regulations, taxes, tradable permits and international treaties. The course also considered sustainability as a new goal for macroeconomic policy.

In 2014 all three of these courses were replaced by $1043 S C G$ Introduction to Environmental Sustainability that sought to learn from the experience of these forerunner courses, utilise the best elements of each and integrate them into a functioning whole (Howlett, Ferreira \& Blomfield 2016). The development process took 18 months and was funded by a Griffith Learning and Teaching Grant (led by a colleague, Dr Henry Skates, from architecture). The relevant educational literature was consulted to provide a sound basis for the course design that was grounded on best practice. International resources were used in compiling the course content. A wide range of consultations took place, with experts from all discipline areas of the school represented. External expertise was also brought in, including the university's sustainability officer, the Griffith Institute for Higher Education (now Learning Futures), an information and communication technology expert, and two educational designers. The new sustainability course was launched in Semester 1 of 2014 (that ran February to June).

\section{Case Study: The Sustainability Course}

The first version of this new course had a modular structure. Module 1 (weeks 1-3) covered the state of the environment, introduced the idea of sustainability, then outlined its key principles. The underlying emphasis of the course was on a values-based approach to sustainability with the commitment to sustainable development at the 1992 Rio Earth Summit viewed as a change in values. Some time was spent explaining the connection between ethics and values using a matrix that ranged from anthropocentric to eco-centric on one axis and deontological to consequentialist on the other. Students were asked to locate themselves on this matrix in order to encourage reflective learning. Module 2 (weeks 4-6) then used the DPSIR framework to explore environmental issues related to the lithosphere, the hydrosphere, the atmosphere, and the biosphere. The approach in this module was largely that of environmental science. In module 3 (weeks 7-9), the focus was on the economy and natural resource management with specific topics covering market theory, market failure and ecological economics. The final module (weeks 10-12) focussed on society and the environment with topics covering culture, indigenous people, settlements and governance. Some conclusions were drawn in week 13 to bring these four modules together. The associated workshops were split between developing basic study skills and reviewing some of the topics covered in the lectures.

The course was completed by 526 students drawn from a broad range disciplines, but the largest cohorts were from planning, architecture, environmental management, science and engineering. There were also students from other groups within the university (including health, business, arts, education and law). All students were surveyed at the end of semester (with a $39 \%$ response rate) to evaluate the quality of the course and teaching. This feedback was used to revise the course content and delivery for 2015. In terms of feedback, the students were very happy with the quality of teaching and the overall satisfaction rating placed the convenor in the top quartile compared to other large first year courses at Griffith. The overall satisfaction with the course, however, was mixed. While the students were generally happy, the rating of the statement that "This course engaged me in Learning" was close to the average when compared to similar first year courses. The student comments suggested that this was because the course appeared to be too general, they could not relate much of what was covered directly to their chosen profession, they wanted more of a focus on finding solutions to issues, and the workshops needed to have a stronger link to the lectures. The discipline-based modular approach also appeared to be a problem with such a broad range of students from different cohorts. Students 
majoring in the environmental and natural science disciplines, for example, enjoyed module 2 but did not engage as well with the economic and social elements of modules 3 and 4 . The opposite appeared to be true for the planning and architecture students.

A detailed content analysis of the survey results was undertaken to identify points for improvement. The convenor then went back to the education for sustainability literature to find suitable innovations. A revised course structure was created and put through an internal peer review process with some of the best performing teachers in the school. The resulting new course structure was implemented in semester 1 (February-June), 2015. This new structure was much more integrated and focussed on fewer topics in more detail. The overall approach shifted to treating sustainability as a design challenge (something that had more resonance with the planning, architecture, engineering and science students) rather than a change in values. The principles of sustainability were still taught, but were used in an applied fashion to explain how they can guide the analysis and solution of problems on a week-by-week basis. The underlying idea was to focus on a key problem in the odd weeks, then work through sustainable solutions in the even weeks. A critical thinking component was added with students exposed to different environmental discourses that challenged mainstream views. Each of the environmental science, economics, policy and cultural studies elements were integrated into every lecture to provide a truly interdisciplinary approach to both problem analysis and problem solving.

Emphasising the relevance of the course to each student's chosen profession was addressed in five ways. First, the lectures of week 1 finished with an explicit discussion of how each of the 11 most common professions being pursued by the students could contribute to addressing the state of the environment and striving for sustainability (these professions were: scientists, planners, architects, engineers, health professionals, business managers, policymakers, lawyers, educators, journalists and social scientists). Second, every lecture included elements that were directly connected to these professions either in analysing or solving a specific problem. This was followed up with 'hands-on' workshops that included specific problem solving exercises related to the issues for that part of the course. Third, the students were asked to look up their chosen profession on the Australian and New Zealand Standard Classification of Occupations (ABS 2015), identify the key tasks, and design a professional e-portfolio targeting potential employers. Fourth, students were given a written assignment to work on over nine weeks that asked them to outline a role for their chosen profession in addressing climate change and how this would fit in with the broader pursuit of sustainability. Finally, specific case studies were used that involved a range of their professions along with some examples of what Griffith graduates were doing.

In 2015 there were 532 students who took the course and both the evaluations of teaching and the course reached into the top quartile compared to equivalent large first year courses. The course was left largely unchanged for 2016 when the course had 495 enrolments. While the evaluations of teaching for this year remained high, satisfaction with the course slipped into the third quartile, so another revision of the course was undertaken based on the student feedback. The 2017 version of the course (which had 493 enrolled students) had just been completed at the time of finalising this chapter. This version of the course updated the material developed in 2015 but merged coverage of key problems and solutions into single weeks. The workshops were updated and there was a new 'big picture' section added to the last 3 weeks covering scenarios for sustainable economies, governments and societies. The most recent student evaluation surveys indicated that the course had risen back to the top quartile when compared to equivalent large first year courses.

The last three years of feedback suggests that finding a course that engages with such a broad range of students with very different interest is a challenge. Three innovations have clearly improved the satisfaction with, and effectiveness of, the course: 1) Looking at sustainability as a design challenge; 
2) Taking an interdisciplinary approach to problem analysis and problem solving; and, 3) More explicitly relating the topics to the chosen professions the students.

\section{The Bigger Picture: Ecological Modernisation}

Treating sustainability as a design challenge is the underlying philosophy of the ecological modernisation which provides the theoretical framework that underpins the idea of sustainability (Howes et al 2010; Howes 2005; Howes 2000). It also offers a strategy for transformation that requires agents for change to operate across all sectors, and the professionals trained by universities can fulfil this role (Howes 2003). Creating interdisciplinary courses in sustainability such as the one discussed in the previous section is therefore important.

Ecological modernisation argues that although the institutions of modernity (i.e. democracy, the state, the market, and industry) have allowed and sometimes even encouraged unsustainable practices, they can be redeemed through a process of transformative change (Christoff, 1996; Mol \& Spaargaren, 2000; Dryzek, 2005; Howes, 2005; Howes et al 2010). The goal is to decouple economic growth from environmental damage by the application of new eco-efficient technology and the redesign of institutions (Berger, 2001; Janicke \& Jacob 2004; Dryzek, 2005; Howes, 2005; Huber 2008; Janicke 2008). This school of thought had its origins in Europe during the early 1980s, and two of its most prominent founders were Martin Janicke and Joseph Huber, although the pedigree of many of its component ideas can be traced back as far as the 1960s (Huber 2000 \& 2008; Janicke \& Jacob 2004; Janicke, 2008). Ecological modernisation ranges from the weak techno-corporatist approach that focusses solely on engineering solutions, to the strong reflexive approach that include the redesign of institutions (Christoff 1996). The state is cast in the role of a facilitator of change, with interventions designed to promote economic prosperity, social wellbeing and ecological sustainability (Howes 2005; Howes et al 2010).

There are five key core themes of transformation in the strong version of ecological modernisation:

1. The redesign of technology to make it more eco-efficient and cleaner (i.e. less material and energy intensive, as well as less polluting);

2. The redesign of economic imperatives to provide incentives for change (e.g. pollution charges and taxes, along with subsidies and tax breaks for sustainable businesses);

3. Political and institutional redesign (i.e. a shift towards a more consensus-based form of governance that encourages partnerships between the state, business and the community);

4. The redesign of the role of social movements to give them more influence in decision making (e.g. engagement with the environmental justice movement); and,

5. A redesign of strategies to constructively engage with public discourse, with greater recognition of social justice and sustainability in decision making (e.g. focussing on green collar jobs as a way to achieve the 'win-win' scenarios) (Howes et al 2010).

The graduates from the Griffith School of Environment are well placed to engage with each of these transformative themes (Dedekorkut-Howes et al 2010). They can (re)design products, processes, buildings, urban spaces and infrastructure to take advantage of eco-efficient technology. They can develop policy, planning and economic regimes that reward sustainable development. They can participate in the establishment of more effective community and business partnerships to rethink development activities. They can establish more effective community engagement and consultation processes for decision making. Finally, they can disseminate information and engage in public forums to promote a more sustainable worldview. Training the students to recognise these opportunities and their role as agents of change is therefore an important responsibility for universities and academics. The sustainability course discussed previously has been designed to make a significant contribution towards meeting this responsibility. 


\section{Conclusions}

While there is an international consensus that the pursuit of sustainability is a good idea, developing a strategy that can catalyse the necessary transformations across all sectors of society has proved difficult. Clearly university graduates have an important role to play in making society more sustainable, but how to prepare them? Environmental education and training has been developing for generations, and at institutions like Griffith University it has merged with education for sustainability within a broader interdisciplinary school. By design, trial and error a series of forerunner courses have led to the development of a new first year foundation course in environmental sustainability that is taken by students from many disciplines across the university. Finding ways to engage such a large and heterogeneous set of students has been a steep learning curve. The current version of the course has adopted a number of strategies, such as treating sustainability as a design challenge that engages students in interdisciplinary problem analysis and problem solving. This approach is consistent with the theoretical framework of ecological modernisation and the idea of sustainability that it underpins. Such a strategy not only guides the education and training of graduates, it also gives them a broader sense of purpose in assisting the pursuit of sustainability.

\section{References}

Australian Bureau of Statistics (ABS), 2015. Australian and New Zealand Standard Classification of Occupations. ABS, Canberra.

Christoff, P., 1996. Ecological Modernisation, Ecological Modernities. Environmental Politics, 5(3), pp. 476-500.

Davis, G., 2006. The rising phoenix of competition: what future for Australia's public universities? Griffith Review (11), pp. 15-31

Dedekorkut-Howes, A., Mustelin, J., Howes, M., and Byrne, J., 2010. Tempering Growth: Planning for the Challenges of Climate Change and Growth Management in SEQ. Australian Planner, 47(3), pp. 203-215.

Dryzek J., 2005. The Politics of the Earth: Environmental Discourses. Oxford University Press, Oxford.

Dryzek, J., Downes, D. Hunold, C. and Schlosberg, D., with Hernes, H-K., 2003. Green States and Social Movements: Environmentalism in the United States, United Kingdom, Germany, and Norway. Oxford University Press, Oxford.

Ecologically Sustainable Development Steering Committee, 1992. National Strategy for Ecologically Sustainable Development. Australian Government Publishing Service, Canberra.

Howes, M., L. Wortley, R. Potts, A. Dedekorkut-Howes, S. Serrao-Neumann, J. Davidson, T. Smith, \& P. Nunn. 2017. "Environmental Sustainability: A case of policy implementation failure?” Sustainability. 9(2), 165; doi: 10.3390/su9020165. On-line: http://www.mdpi.com/2071-1050/9/2/165/htm

Howes, M., Dedekorkut-Howes, A., Sipe, N., and Coiacetto, E., 2011. Broadening Horizons: Teaching planning students about climate change at the Griffith School of Environment. World Planning Schools Conference, 4-8 July, Perth.

Howes, M., McKenzie, M., Gleeson, B., Gray, R., Byrne, J., Daniels, P., 2010. Adapting the idea of ecological modernisation to the Australian context. Journal of Integrative Environmental Sciences, 7(1), pp. 5-22.

Howes, M., 2005. Politics and the Environment: Risk and the role of government and industry. Allen \& Unwin, Sydney/ Earthscan, London. 
Howes, M., 2003. The Environmental Academic. Spinifex. Queensland Conservation Council, December, 24(4), pp. 6-7.

Howes, M., 2000. A Brief History of Commonwealth Sustainable Development Policy Discourse. Policy, Organisation \& Society, 19(1), pp. 65-85

Howlett, C., Ferreira, J. and Blomfield, J. 2016 . Teaching Sustainable Development in Higher Education: Building Critical, Reflective Thinkers through an Interdisciplinary Approach. International Journal of Sustainability in Higher Education, 17(3), pp. 305321.

Huber, J., 2008. Pioneering countries and the global diffusion of environmental innovations: These from the viewpoint of ecological modernisation theory. Global Environmental Change, 18 , pp. 360-367.

Huber, J., 2000. Towards Industrial Ecology: Sustainable development as a Concept of Ecological Modernization. Journal of Environmental Policy \& Planning, 2, pp. 269285.

Janicke, M., 2008. Ecological Modernisation: new perspectives. Journal of Cleaner Production, 16, pp. 557-565.

Janicke, M. and Jacob, K., 2004. Lead Markets for Environmental innovations: A New Role for the Nation State. Global Environmental Politics, 4(1), pp.29-46.

Lyth, A., Nichols, S., and Tilbury, D., 2007. Shifting Towards Sustainability: Education for Climate Change in the Built Environment Sector. Australian Research Institute in Education for Sustainability (ARIES), Macquarie University, Sydney.

Markwell, D., 2007. A Large and Liberal Education: Higher Education for the 21st Century. North Melbourne: Australian Scholarly Publishing.

Metcalf, W., 2000. Evolution of environmental sciences: the first 25 years. Griffith University, Brisbane.

Mol A., and Spaargaren G., 2000. Ecological Modernisation. Environmental Politics, 9(1), pp. 17-49.

Palmer, J., 1998. Environmental Education in the 21st Century: Theory, Practice, Progress and Promise. London, Routledge.

Quirke, N., 1996. Preparing for the future: a history of Griffith University, Boolarong Press: Brisbane.

United Nations (UN). 2015. Sustainable Development Goals. New York, United Nations. Online: http://www.un.org/sustainabledevelopment/sustainable-developmentgoals/\#prettyPhoto

United Nations. 2013. Higher Education Sustainability Initiative (HESI). UN Sustainable Development Knowledge Platform.

United Nations, 1972. Declaration of the United Nations Conference on the Human Environment, New York, United Nations.

UNCED (United Nations Conference on Environment and Development), 1992. Agenda 21. United Nations, New York.

United Nations Environment Program, 2012. Global Environmental Outlook (GEO-5) Assessment Report. UNEP: Nairobi, Kenya.

United Nations Educational, Scientific and Cultural Organisation UNESCO. 2014. UN Decade of Education for Sustainable Development 2005-2014: The DESD at a Glance. Paris. 
Wilensky, M., 2007. Tertiary Education for Sustainability: Four Australian Universities' Commitment to Sustainability. Washington University, St. Louis.

WCED (World Commission on Environment and Development) 1987. Our Common Future. Final Report to the United Nations, New York. 